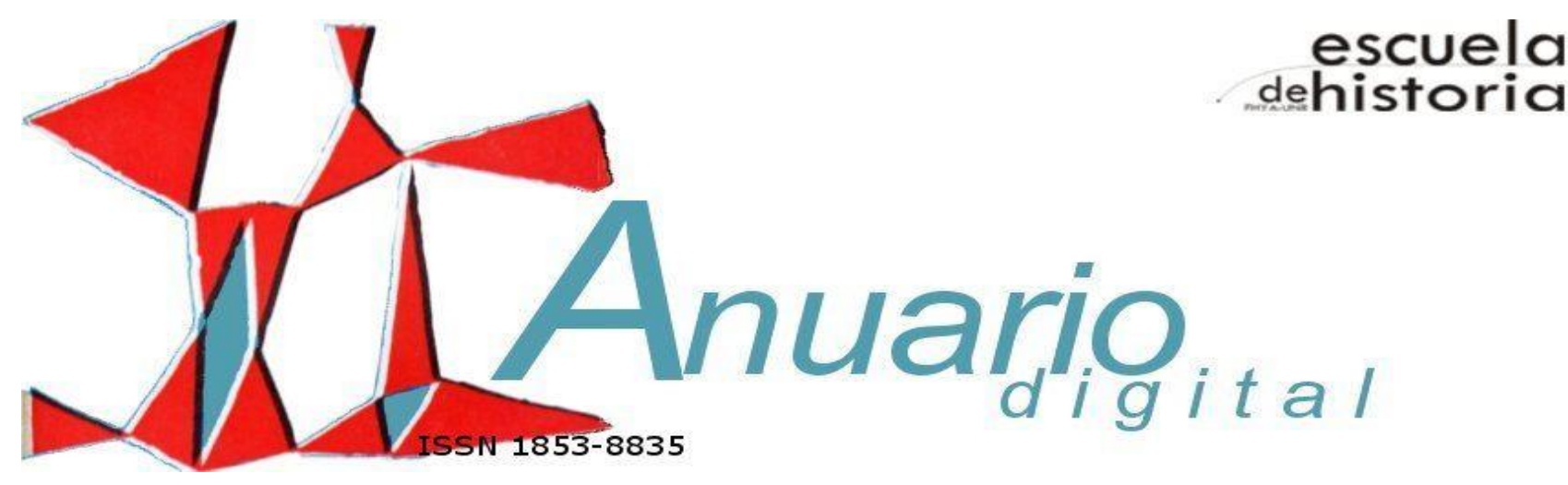

\title{
El “Nuevo Catolicismo” en Córdoba durante las primeras décadas del siglo XX
}

\author{
"New Catholicism" in Cordoba during the first decades of the XXth Century
}

GARDENIA VIDAL*

(Universidad Nacional de Córdoba); Argentina gardeniavidal13@gmail.com

Este artículo se inspira en la noción de "nuevo catolicismo" desarrollada por Cristopher Clark quien sostiene que en el oeste europeo durante el s. XIX la jerarquía eclesiástica y los militantes laicos confrontaban sus ideas, constituyendo facciones en el interior de la Iglesia, es decir mientras el "nuevo catolicismo" se construía, no sin problemas entre los dirigentes, los sectores populares crecían y se organizaban, dejando atrás el integrismo medieval y se apropiaban de estilos modernos de organización, más allá de los problemas intelectuales y doctrinarios que preocupaban a las élites.

El trabajo que desarrollo en esta oportunidad utiliza ese concepto para aplicarlo a lo sucedido en la ciudad de Córdoba. Por un lado, ciertamente, la fragmentación de la élite católica, es un hecho que se manifiesta de diversas maneras; no obstante simultáneamente se producía el crecimiento y organización de los sectores populares católicos y los fieles ganaban las calles mediante variadas demostraciones, en gran medida apoyados, al menos en parte, por esa misma élite.

\footnotetext{
* Investigadora y docente, FFyH-UNC (área Historia). Agradezco a Diego Mauro sus sugerencias, sobre una versión preliminar de este artículo.
}

Esta obra está sujeta a la Licencia Reconocimiento-NoComercial-CompartirIgual 4.0 Internacional de Creative Commons. http://creativecommons.org/licenses/by-nc-sa/4.0/ 
Palabras clave: Nuevo Catolicismo; Élites; Sectores Populares; Fragmentación; Modernización

ABSTRACT

This paper is inspired by the notion of "New Catholicism" developed by Cristopher Clark who argues the in Nineteenth Century Western Europe, the Catholics elite developed their ideas in a way the led to fragmentation. As the popular sectors grew in size and numbers of organizations, they modernized their religious practices, setting aside the elite's intellectual and doctrinal arguments.

This work takes that idea in order to apply it to the City of Cordoba at the beginning of the Twentieth Century. It is true the differences with Europe are huge; nevertheless the elite's fragmentation was present while popular sector organized increasingly in modern ways and participated in big public demonstrations. However, the same elite lead many of these events.

Keywords: New Catholicism, Elites, Popular Sectors, Fragmentation, Modernization

\section{Introducción}

Cuando comencé a pensar este artículo la idea que me orientaba la había extraído de uno de los argumentos centrales elaborado por Cristopher Clark en su artículo "The New Catholicism and the European culture wars"1 ${ }^{1}$. El mismo consiste en lo siguiente: en tanto la jerarquía eclesiástica y los militantes laicos en el siglo XIX confrontaban sus ideas, entablaban conflictos importantes debido a las mismas, se fragmentaban constituyendo facciones en el interior de la institución; es decir mientras el "nuevo catolicismo" se construía, no sin problemas entre los dirigentes, los sectores populares crecían y se organizaban, dejando atrás el integrismo medieval y se apropiaban de estilos modernos de organización, más allá de los problemas intelectuales y doctrinarios que preocupaban a las élites. El trabajo que desarrollo en esta oportunidad utiliza ese concepto para aplicarlo a lo sucedido en la ciudad de Córdoba, Argentina. Por un lado, ciertamente, la fragmentación de la élite católica, por motivos partidarios -se enrolaban en diferentes partidos desde 1890 en adelante-, concepciones distintas de la modernización de la política y, seguramente, miradas doctrinales e intelectuales diversas es un hecho que se manifiesta en innumerables

${ }^{1}$ Clark, Christopher; "The New Catholicism and the European Culture Wars", en Clark Christopher and Kaiser Wolfram, Culture Wars: Secular-Catholic Conflict in Nineteenth Century Europe; Cambridge University Press; New York; 2003.

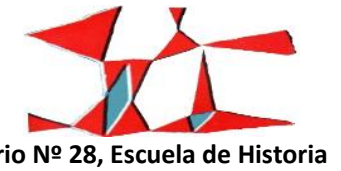

Facultad de Humanidades y Artes (Universidad Nacional de Rosario), 2016 
ocasiones. Por otro, el crecimiento y organización de los sectores populares católicos se producía y parte de esta élite no era ajena a ese proceso, es decir, este avance organizacional con claros tintes de demandas asistenciales no provenía exclusivamente de los grupos subalternos, sino que la dirigencia católica, ya perteneciente al clero secular, regular o laica, inspirada en la doctrina social de la iglesia contribuía para que esto sucediera.

Con todo, parte de la élite católica claramente refractaria a los cambios persistió durante las primeras décadas del siglo XX, aunque la mayoría trató de adaptarse a los nuevos tiempos, -muchas veces de manera asistemática ya que nunca se organizó un partido católico en Córdoba-, no pudieron articular siquiera una corriente que respondiera al catolicismo social. No obstante, las asociaciones que respondían a esta visión se multiplicaron y atrajeron a una gran cantidad de personas de todos los niveles sociales. Esto es palpable al observar el alto número de peregrinos que participaban en las procesiones, en particular las más destacadas por la iglesia como la de Corpus Christi. Empero, la dirigencia integrista persistió y no dejó de imprimirle a esta masificación del catolicismo su percepción de la sociedad. En ese sentido, el "nuevo catolicismo"2 que se genera a comienzos de siglo en Córdoba es fruto de una tensión doctrinaria y política, entre los dos extremos más visibles (el integrismo y los hombres defensores del catolicismo social); aunque eso no niega la gran cantidad de grises importantes que se encontraban en ese amplio espacio que ocupaba el "medio", pese a que no encontremos una línea de pensamiento claramente definida como en otras ciudades (Rosario, Buenos Aires) respecto del catolicismo social. ${ }^{3}$

La estructura del artículo es la siguiente. En un primer apartado, realizo una reconstrucción de la dirigencia más refractaria a las transformaciones, a posteriori me detengo, a fin de presentar un muestreo, en una breve mención de algunas asociaciones que van modernizando el mundo católico al estilo de lo solicitado por León XIII y la Doctrina Social de la Iglesia. Finalmente; en tercer lugar presento con detenimiento una de estas asociaciones -Asociación Católica de Artesanos de San José- y explico su funcionamiento y estructura. Mi hipótesis central es por un lado que la construcción del "nuevo

\footnotetext{
2 Utilizo esa noción para este periodo porque me detendré fundamentalmente a señalar la acción de la élite notabiliar que sigue pugnando por permanecer intocable y la masificación de la política, iniciada en 1912 que a nivel de la institución iglesia se refleja en la ocupación de las calles por los feligreses cada vez que son convocados.

${ }^{3}$ No quiero dejar de insistir que el catolicismo social en Córdoba no se encuentra organizado como grupo fácilmente identificable, sino como individuos que participaron en distintas asociaciones, actos, etc. que demostraban su preferencia por el mismo.
}

41

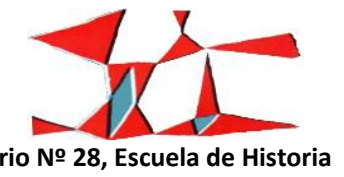

Facultad de Humanidades y Artes (Universidad Nacional de Rosario), 2016

pp. 39-68

ISSN 1853-8835 
catolicismo" en Córdoba es el resultado de una resistencia entre los polos mencionados y los sectores más moderados, aunque en esta ciudad ocurrió un hecho singular, La Reforma Universitaria, que los impulsó a concentrarse en varias ocasiones sin posibilidades de discusión para enfrentarla. Ese movimiento estudiantil, se produce desde el famoso año 18 , pero continúa durante toda la década del veinte, de allí que los momentos de unidad puedan sobresalir en las fuentes, pese al dinamismo de ideas diferentes que socavaban el cauce de un espacio, necesariamente pospuesto a un segundo plano, ante un adversario tan decidido.

Córdoba se caracterizaba porque su élite política, judicial, universitaria se identificaba en gran parte con el conservadorismo-católico, a la vez que era lo suficientemente extensa, como para estar presente en todas las actividades públicas. Como se sabe, el movimiento universitario reformista que estalla en 1918 tiene como objetivo principal modernizar la Universidad y entre uno de sus reclamos más reiterados y conflictivos estaba la erradicación de esa élite ligada al tradicionalismo más retrógrado, el "jesuitismo" como lo denominaban los estudiantes. El Poder Judicial no estaba exento de esa ubicuidad conservadora; respecto de la política partidaria, la situación no difería de los espacios mencionados. Antes de 1912, estos grupos estaban presentes en la Unión Provincial, en el Partido Constitucional, en la Unión Cívica -luego en la Unión Cívica Radical-, en la Unión Nacional e incluso en el PAN. Al conformarse y consolidarse los dos partidos mayoritarios de Córdoba: el Partido Demócrata (1913) y la UCR, estos cuadros invadieron las dirigencias de ambas agrupaciones, hecho que colaboró a persistentes conflictos internos por la diversidad ideológica, de intereses y prácticas que insertaban en cada uno de ellos. De allí que en uno de mis primeros trabajos de investigación sobre los partidos políticos cordobeses entre 1912 y $1930^{4}$, sostengo que el catolicismo aparece como un poder suprapartidario que influía en buena medida el trazado de las estrategias de ambos partidos políticos.

El periodismo no escapaba a ese influjo, al contrario los católicos fueron los más consecuentes con la publicación y sostenimiento de una prensa moderna que respondía a sus intereses espirituales y políticos: desde 1860 con El Eco de Córdoba, luego El Porvenir y por último, Los Principios (1894), que vio la luz durante casi todo el siglo XX, hasta $1982^{5}$. La existencia y persistencia de esta prensa comparada con otras

\footnotetext{
${ }^{4}$ Vidal, Gardenia; Radicalismo de Córdoba 1912-1930. Los grupos internos: alianzas, conflictos, ideas, actores; Dirección General de Publicaciones Universidad Nacional de Córdoba; Córdoba; 1995.

${ }^{5}$ En realidad, el medio estuvo manejado por la curia hasta 1976, luego fue adquirido por otra empresa privada.
}

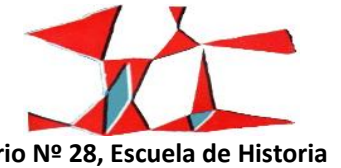


provincias (salvo Buenos Aires con El Pueblo 1900-19606) habla de por sí del poder político sistematizado aunque internamente fragmentado- del catolicismo en esta ciudad. Con todo, en el campo periodístico siempre existió su contraparte como La Carcajada, El Progreso, y por fin La Voz del Interior (1904actualidad), acérrima opositora a los dirigentes y la propaganda católicos, desde antes y después de convertirse en un medio que respondía al Radicalismo Personalista. El diario Córdoba (fundado en octubre de 1928) y El País (vocero de una corriente del PD), entre otros medios gráficos tampoco respondían al catolicismo. O sea el espacio ocupado por el periodismo estaba claramente dividido, en particular sobre la cuestión ideológico-religiosa, dado que coincidieron en otros tópicos -sociales, económicos, culturales- en más de una ocasión.

El otro punto a destacar es que la prensa católica, al menos hasta la década del veinte, era la que aparecía con una línea editorial clara, precisa, previsible acerca de cualquiera de los temas que abordaba. No sucedía lo mismo con los otros diarios. La Voz del Interior, por ejemplo cuando se convirtió en vocera del Radicalismo Rojo se destacaba por un anticlericalismo acérrimo; posteriormente (hasta 1925 aproximadamente) variaba constantemente respecto del apoyo o la crítica que hacía a los candidatos de uno u otro partido mayoritario. ${ }^{7}$

¿Cómo actuaron los encargados y redactores de Los Principios respecto de los partidos políticos? Algunos nombres nos indican que eran militantes del PD -el director del diario hasta 1927, Segundo Dutari Rodríguez pertenecía a esa agrupación. Por el momento, no he descubierto a algún dirigente radical que trabajara sistemáticamente en este medio, lo cual no significa que en la UCR no estuviera afianzada el ala

\footnotetext{
${ }^{6}$ En diciembre del 1954 fue clausurado en el marco del conflicto entre gobierno e iglesia. Posteriormente, continuó saliendo, incorporando nuevos temas y con un formato diferente, como ediciones temáticas y extraordinarias. Después de la "Revolución Libertadora", el diario no pudo reponerse a pesar de su intento de modernización. Se convirtió en un medio antiperonista, pero dejo de ser viable económicamente y no pudo competir en el mercado nacional. El último número es de abril de 1960 (Agradezco esta información al Dr. Ariel Fresia).

7 Luego de 1912, aparece tímidamente como defensora de la UCR; cuando la escisión de esta, se convirtió en el vocero del Radicalismo Rojo y archienemiga de Hipólito Yrigoyen; en este marco no dudó en apoyar la corriente liberal del Partido Demócrata. Por consiguiente, su identificación más nítida se relacionaba con su anticlericalismo que llegó a ser irreverente una vez que comenzó a fortalecerse un "público" contra hegemónico libre pensador. Un ejemplo extremo se observa en un comentario que el diario realiza en 1924 sobre una procesión católica, la que había sido exitosa, según LP, por el número de asistentes. El título de la nota es: "La Virgen está para comérsela"; luego de defenestrar de variadas formas a los sectores que concurrieron al acto por ricos, por marginales, por ignorantes, etc., termina diciendo: "Pero hablando de esta santa [la virgen] iba esplendente en su hermosura, que resaltaba entre el oro de sus alhajas y el lujo de sus telas. Lucía un traje charmeuse con encajes de Irlanda. Bien aseadita, ni una arruga en las enaguas, sin una manchita de esas que ponen las irreverentes moscas. Estaba como para comérsela a besos. Parecía una novia el día que le dan el anillo (...)" LVI, 25-09-24
}

43

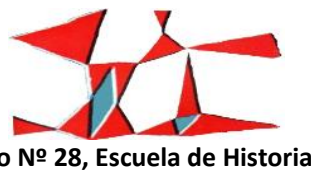

Anuario № 28, Escuela de Historia

Facultad de Humanidades y Artes (Universidad Nacional de Rosario), 2016

pp. 39-68

ISSN 1853-8835 
conservadora católica ${ }^{8}$. Pero a mediados de la década del veinte, cuando se intenta conformar un partido católico, los integrantes del mismo se habían escindido transitoriamente del PD. La prensa católica como vocera del catolicismo sin distinciones facciosas publica las posiciones de todas ellas; aunque es notable el énfasis que otorga a los emprendimientos del catolicismo social. Con todo cabe aclarar que su director, si bien apoyaba a estos grupos activamente también estaba a la cabeza de organizaciones políticas elitistas, como veremos más adelante.

El "nuevo catolicismo", en consecuencia, se desarrolla en Córdoba como en la mayoría de los lugares mencionado por Clark con muchos matices y variados agentes. La dirigencia notabiliar no solo no desaparece durante el periodo en estudio, sino que algunos de sus integrantes se constituyen en elementos realmente refractarios al avance de la democracia cristiana; no obstante y ya desde el s. XIX la práctica social de algunos eclesiásticos y laicos propenderá a la organización de un asociacionismo con fines asistenciales. De allí que la tensión vivida por ese conservadorismo arcaico y las nuevas propuestas fue constante, aunque estas últimas lograron proliferar y los dirigentes más retrógrados se verán obligados a compartir con ellos su posición, estimulada, además por la Jerarquía Eclesiástica, en particular desde la publicación de la Encíclica Rerum Novarum en 1891.

Es probable que varios de esos católicos integristas, o la corriente que representaban, pasaran a formar parte de la Unión Nacional de Córdoba (fascista) en la década del ‘30.

\section{Las posiciones refractarias a la modernidad del catolicismo notabiliar}

Ya aprobada la Reforma Electoral en 1912, Los Principios transmitía sin eufemismos su contrariedad por el sufragio universal y defendía la necesidad de la existencia de una dirigencia elitista capaz de pergeñar un plan de gobierno, junto con un grupo de ciudadanos "lúcidos que supieran votar bien" como elementos indispensables para reformar el régimen político: "El pueblo no tiene aquí ni en ningún país ideas de gobierno porque la ciencia política no es de las multitudes (...) necesita, por ende, de la dirección de los pocos que son capaces de idear un plan y llevarlo a la práctica. Mientras esto no se realice, el pueblo votará

\footnotetext{
8 Uno de los pocos radicales, cuyos artículos aparecieron en LP con comentarios muy laudatorios fueron los de Arturo M. Bas, simpatizante primero y luego afiliado a la UCR.
} 
y constituirá gobierno, pero (...) no podrá decirse que los elegidos por él sean sus genuinos representantes"9.

La incapacidad del pueblo para elegir a sus representantes -un pueblo demasiado heterogéneo con la llegada de los inmigrantes- convertía al voto no solo en una quimera, sino fundamentalmente en un peligro: "El sufragio universal y absoluto como medio de establecer una democracia progresista es una utopía fatal que lleva el virus de la disolución a las repúblicas que lo han adoptado (...) si esto es así en todos los pueblos, ¿qué había de ser en el nuestro cosmopolitizado por la inmigración de las bajas clases europeas?". ${ }^{10}$

El individuo abstracto diseñado desde la Revolución Francesa, ${ }^{11}$ e identificado con la masculinidad, se presentaba para esta dirigencia con una variante notable: la referencia no era con los hombres en su conjunto, sino con los hombres lúcidos. Esta clara diferenciación clasista ${ }^{12}$-el género no aparecía en la agenda- persistirá en el discurso y la práctica católicos y se convertirá en una influencia importante del estilo paternalista que caracterizó el sistema político argentino, claro que sin los excesos de las frases antes citadas.

La posición contraria a la expansión de la ciudadanía tiene piezas asombrosas entre algunos intelectuales cordobeses. Unos años antes, en 1907, en su tesis de doctorado en Derecho y Ciencias Sociales, José Garzón Funes evidenciaba palmariamente esa visión del mundo descalificadora del "pueblo". La tesis se titula "Principios fundamentales sobre sufragio" y trata precisamente de la organización política y de la categoría de ciudadano. Para el autor -conforme señala Liliana Cháves ${ }^{13}$ - los gobiernos se guiaban por la virtud o la corrupción. En tanto él consideraba que las democracias se inclinaban por esta última, era necesario instrumentar los medios para adaptarlas a la virtud; para ello este sistema debía edificarse en

\footnotetext{
${ }^{9}$ LP 11-04-13. Cit. por Roitenburd, Silvia; "El papel de las mayorías en el proyecto global del nacionalismo católico (1910-1919)", en El Reformismo en Contrapunto. Los procesos de modernización en el Río de la Plata (1890-1930); CLAEH: argumentos; Montevideo; $1989 ;$ p. 31.

${ }^{10}$ LP 25-03-14- Cit. por Roitenburd, Silvia; "El papel de las mayorías en el proyecto global del nacionalismo católico (1910-1919)", en El Reformismo en Contrapunto. Los procesos de modernización en el Río de la Plata (1890-1930); CLAEH: argumentos; Montevideo; 1989; p.31.

${ }^{11}$ Scott, Joan Wallach; La mujeres y los derechos del hombre. Feminismo y sufragio en Francia, 1789-1944; Siglo XXI; Buenos Aires; 2012 [1996]; pp. 15-24.

${ }^{12}$ Digo clasista porque la "lucidez", la capacidad intelectual se la asociaba a los sectores de mayores recursos.

${ }^{13}$ Chaves, Liliana; Tradiciones y Rupturas de la Élite Política Cordobesa (1870-1880). La clave conservadora de la modernización política; Ferreyra Ed.; Córdoba; 1997; pp. 119-123.
}

45

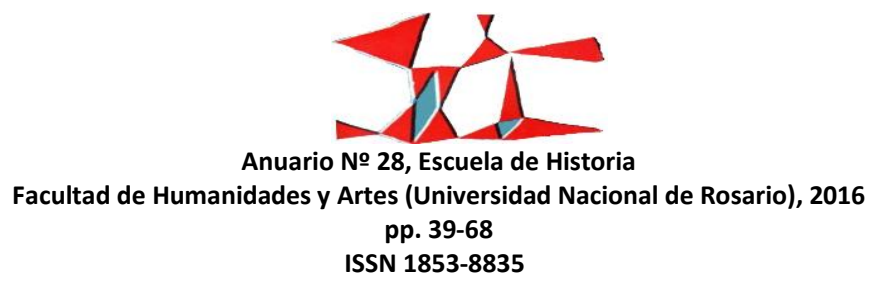


base a una concepción orgánica y jerárquica de la sociedad. En ese contexto, el derecho de voto no derivaba de la "naturaleza del individuo", sino del "estado" en el que cada uno estaba inserto y en consecuencia se preguntaba retóricamente sobre la soberanía: “Ahora bien: ¿cuál es el origen de la soberanía? (...) Subiendo de escalón en escalón hasta la fuente primera, hemos de llegar a un punto en que nos encontremos con que no se halla en ninguna de las individualidades existentes en el mundo, y tendremos que remontarnos más alto, hasta poder señalar a alguien que la resuma y la contenga: Dios. Allí está la fuente y de ella deben partir las cuestiones primeras y segundas que dimanen"

La soberanía popular, entonces, era objetada porque desconocía las diferencias y las jerarquías naturales: “Aquél que proclamó la soberanía absoluta del pueblo, proclamó la muerte de la libertad; aquel que proclamó la igualdad absoluta de los hombres en todos los órdenes, proclamó la disolución social. La soberanía del pueblo es el despotismo de las masas; y el despotismo anónimo es el peor (...) Sostener que el pueblo es soberano es seguir la doctrina del pacto social, que ha servido de base a los teorizadores y declamadores modernos de la omnipotencia e infalibilidad del pueblo".

Estos argumentos son claramente anteriores no solo a la llustración, sino a posturas del siglo XVII como las de los levellers en las guerras civiles inglesas o incluso a la visión que la oligarquía de las Provincias Unidas va construyendo durante la guerra por su independencia desde fines del s. XVI.

Pese a los cambios que experimentaba la institución Iglesia en todo el mundo occidental como se observa, en Córdoba no desapareció ese grupo de notables autoritarios que desacreditaban la participación política de los sectores subalternos. El área en la que mejor se reflejaba esta actitud era en relación al derecho al sufragio y a la idea de soberanía.

En la primera mitad de la década del veinte y como consecuencia de la abstención electoral de la UCR, dirigentes católicos provenientes del PD con el fin de evitar que el tercio de los legisladores que debía ocupar el segundo lugar recayera en hombres del Partido Socialista o Comunista, decidieron conformar una agrupación que crecería -aunque tímidamente- hasta obtener el nombre de Partido Popular. LP apoyaban entusiastamente este proyecto y se preguntaba: "Si los católicos son los más en Córdoba ¿por qué no se unen para gravitar en los comicios? ¿Qué hacen dispersos en el seno de las agrupaciones políticas? (...) ¿Qué papel representan en esos conglomerados partidarios en que la política los destiñe e inutiliza como

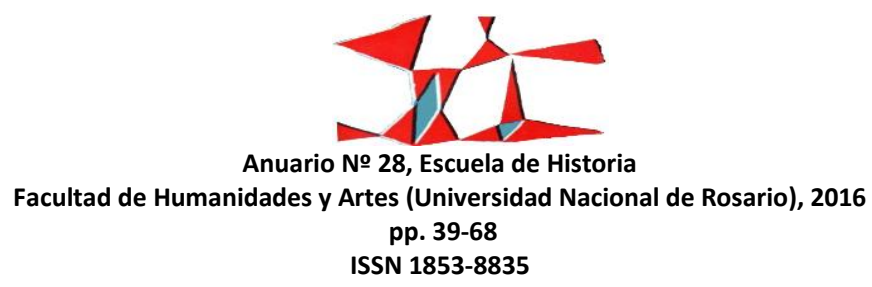


fuerza efectiva para la acción? (...) ¿No hay alguien que levante su autorizada voz llamando a la organización de fuerzas y a la acción de todos los católicos?" Cabe especular que, ante la inexistencia de una corriente que respondiera al catolicismo social, el diario como algunos dirigentes católicos se agruparan en estos emprendimientos, ciertamente, reacios a la modernidad.

En el caso del Partido Popular, Antonio Nores, el candidato a rector por la Corda Frates en 1918 y elegido efectivamente para cubrir ese cargo, se convirtió en el ideólogo y principal propulsor de la propuesta. Conforme se deduce de la prensa, se puede señalar que eran defensores de una organización socio-política que se instrumentara en base al principio de una autoridad sacralizada, de un orden institucional y social establecido y controlado desde arriba por una élite que impusiera también el respeto por las tradiciones hispánicas, la defensa de la moral cristiana, sustentado todo ello en la re significación del concepto de nacionalidad. La religión católica se constituía en el elemento fundante del proceso de construcción de la Nación y, por lo tanto, de la identidad nacional ${ }^{14}$. Hasta acá, probablemente no existiera gran diferencia con las ideas que podía defender un católico social, pero además los adherentes no se cansaban de negar la validez de los partidos políticos. De allí que uno de los candidatos, dijera “...colaboraré ante todo y con prescindencia de toda política en pro del orden institucional y del afianzamiento del principio de autoridad como base de todo progreso"15.

Mientras otro sostenía "defenderé en el parlamento la causa conservadora y la fe de mis mayores, vale decir todo cuanto constituye el tradicionalismo de la sociedad argentina"16. Esas ideas, negadoras de la alteridad y la diferenciación, se fortalecieron y, probablemente se reestructuraron, luego de la Gran Guerra, la Reforma Universitaria y la aparición del Partido Comunista ${ }^{17}$. A nivel internacional, el cuestionamiento al liberalismo, considerado la causa principal de la contienda, comienza a ceder espacios ante la aparición de nuevos paradigmas como el corporativismo. El periodo de posguerra continuó mostrando carencias graves

\footnotetext{
${ }^{14}$ Estas conclusiones se extraen de la lectura del diario LP desde 1919 a 1924

${ }^{15}$ LP 19-03-21. El personaje era Rafael Moyano López

${ }^{16}$ LP 10-03-21. Se trata de José Cortés Funes.

${ }^{17}$ Sobre la historia del Partido Comunista de Córdoba desde su fundación hasta 1927, consultar: Zandrino, Estefanía; Tesis de Grado “El Partido Comunista de Córdoba (1918-1927): origen, organización, dirigencia, relación con el mundo del trabajo y estilos de sociabilidad"; Escuela de Historia; FFyH-UNC; 2013. Zandrino, Estefanía, "Estilos de sociabilidad en el interior del Partido Comunista de Córdoba (1918-1927)" y Zandrino, E., Vidal, G, "Una aproximación al Partido Comunista de Córdoba desde su fundación hasta fines de la década del veinte"; en Gardenia Vidal y Jessica Blanco (eds.); Espacio público en Argentina, fines s. XIX-primera mitad s. XX. Partidos, catolicismo, sociabilidad...; Ed. Brujas; Córdoba; 2016.
}

47

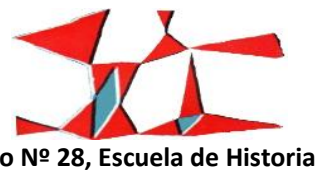

Facultad de Humanidades y Artes (Universidad Nacional de Rosario), 2016

pp. 39-68

ISSN 1853-8835 
del modelo liberal. En Córdoba, la pobreza estaba extendida, el funcionamiento del régimen político era cuestionado desde diferentes sectores de la opinión pública, y en cuanto a la esfera económica, es sabido que la crisis desatada por la guerra exigía el replanteo de algunas cuestiones esenciales del sistema.

El "tradicionalismo" y el "nacionalismo" aparecen como elementos constitutivos de esa concepción alternativa al liberalismo que se estaba configurando. En Córdoba tenía apoyos decididos dentro de la élite católica. En la Convención de la Reforma Constituyente de 1923, al discutirse el tema Educación y, sobre todo, la cuestión clave del laicismo, el representante demócrata Lisardo Novillo Saravia no dudó en defender el proyecto de Mussolini como una opción válida y elogiable para la "civilización naturalista" y sus consecuencia más desgraciada: el "laicismo": “(...) Los tiempos han cambiado y hoy, una fuerte corriente espiritualista y religiosa agita los espíritus y sacudiendo la conciencia y responsabilidad de los hombres dirigentes nos señalan nuevos rumbos. Mussolino (sic) (...) 'el hombre épico de los tiempos contemporáneos' como se le ha llamado, este extraordinario conductor de multitudes, ha hablado bien claro y bien alto para que le oigan Italia y el mundo entero. 'La gran experiencia de posguerra, ha dicho, señala la derrota del liberalismo; los hombres de hoy en día están cansados de la libertad, han tenido una orgía de libertad y ésta ya no es la severa y casta doncella por quien las generaciones de la primera mitad del siglo pasado han muerto'. Mussolino (sic) afirma con las palabras y los hechos que se necesitan ahora otras palabras de orden cuales son las de jerarquía y disciplina". ${ }^{18}$

Esto queda notablemente al descubierto a mediados de la década del veinte cuando, como dije, un grupo de católicos proveniente del PD intenta crear un partido confesional. La respuesta que da Gustavo Franceschi a esta idea es muy ilustrativa sobre varios temas, pero en esta oportunidad me interesa marcar lo siguiente. Franceschi ${ }^{19}$ señalaba que el momento por el que atravesaba la política en Argentina podía ser considerado como propicio para la formación de un partido católico en la medida que fuera una asociación

\footnotetext{
${ }^{18}$ HCR: Diario de Sesiones de la Honorable Convención Reformadora de la Constitución. Provincia de Córdoba, 1923, Tomo I, p. 912. En 1930, será un hombre de la UCR, Agustín Garzón Agulla, Ministro de Hacienda y Gobierno quien utilizará la misma fundamentación que Novillo Saravia, para defender la enseñanza religiosa en las escuelas del estado y hará explícita su admiración por Mussolini. En rigor de verdad no solo los católicos admiraban la figura del Duce. Poco después de la Marcha sobre Roma, en 1922, Leopoldo Lugones, conocido por su anticlericalismo, declaraba "Italia acaba de enseñarnos cómo se restaura el sentimiento nacional, bajo la heroica reacción fascista encabezada por el admirable Mussolini" Rock, David; La Argentina autoritaria. Los nacionalistas, su historia y su influencia en la vida pública; Ed. Ariel; Buenos Aires; 1993; p. 88.

19 La opinión de Gustavo Franceschi aparece en dos artículos publicados por Los Principios: 23-06-22 y 30-06-22.
}

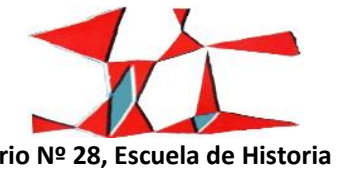

Facultad de Humanidades y Artes (Universidad Nacional de Rosario), 2016

pp. 39-68

ISSN 1853-8835 
de índole social y de confesionalidad atenuada ${ }^{20}$. Dudaba si era conveniente de excluir a alguna clase social, porque eso podía provocar conflictos importantes. Y más importante para mi argumento general, manifestaba su oposición a las posturas aristocratizantes como las del Dr. Nores y enfatizaba “... [S]ueñan con cosas vanas aquellos elementos de cierta clase que imaginan que el pueblo los seguirá tan sólo porque llevan un apellido más o menos conocido o porque se proclaman jefes del catolicismo". Por fin, advertía que "la masa" exigía su inclusión política y social, mediante un programa profundamente reformista pero, a la vez, temía de las resistencias y conflictos que podía desencadenar. Es evidente que la posición de Franceschi se identifica con el nuevo catolicismo e incluso con lo que se denomina catolicismo social, por moderado que fuera. Como dije, en Córdoba es difícil advertir una corriente compacta que se identificara con esta línea social, aunque encontramos protagonistas aislados de quienes no tenemos duda de caracterizarlos con ese apelativo: solo para mencionar a los más destacados señalo a Emilio E. Sánchez, Manuel Maciel, Juan F. Cafferata, entre muchos otros. También es llamativo, aunque demostrativo de las tensiones existentes en el proceso de formación del "nuevo catolicismo" cómo algunos hombres -Dutari Rodríguez, por ej.constituyeron figuras importantes de la dirigencia del catolicismo social, pero a su vez, como miembro del PD, no vaciló en formar parte del Partido Popular en 1924 con ese halo aristocratizante y contrario a otorgar los derechos ciudadanos a todos los hombres.

\footnotetext{
${ }^{20}$ Franceschi se preguntaba y respondía sobre ¿Por qué podría ser un momento favorable para la formación de un partido católico en esa coyuntura? Porque conforme decía textualmente "Se está dictando o por lo menos estudiando, en estos años la legislación social fundamental de nuestro país... y sería sumamente positivo que esas leyes fueran impulsadas y promovidas por un Partido Social Cristiano. La no participación de los católicos daría lugar a que esas leyes se elaboraran con un criterio liberal de errado conservatismo o bien con un criterio lindero del socialismo de estado". Pero inmediatamente agregaba que con ese solo elemento no se podía asegurar la factibilidad de la formación del PSC. Se necesitaba además contar con otros factores: las masa, los dirigentes, el programa, la disciplina partidaria para darle "verdadero cuerpo y trascendencia" a un partido de ese tipo. En cuanto al primer punto, indicaba que "al margen de lo que se dice de la libertad de sufragio, hay que tener en cuenta el caudillismo". Advertía que esa práctica, muy extendida, era un obstáculo enorme para el desarrollo de una agrupación de ideas porque "estos caudillos son en su casi totalidad inaccesibles a las ideas doctrinarias y no se mueven más que por conveniencia". Solo se lograría vencer el fenómeno caudillista si "la masa de los católicos se hallara profundamente penetrada de la doctrina social de la Iglesia", cosa que no ocurría por entonces. Agregaba que el programa económico-social del catolicismo era conocido solo por una minoría de personas y por lo tanto era difícil trasladarlo al campo político. En referencia a los dirigentes, Franceschi se preguntaba ¿dónde reclutarlos para una agrupación política de índole social cristiana? Vislumbraba dos problemas esenciales vinculados al espacio y a la clase social. No bastaba con tener algunos dirigentes en las grandes ciudades, se los requería en cada población donde hubiera un núcleo de electores. Era difícil conseguir esa cantidad para un partido de este tipo; además había que buscarlos entre el elemento laico que ciertamente era escaso en número y formación. El sector social del cual deberían provenir estos dirigentes era uno de los mayores problemas. La experiencia europea mostraba que los reclutaba mayoritariamente de la clase media profesional y asalariada; y concluía señalando que en Argentina no había suficientes dirigentes de este tipo.
}

49

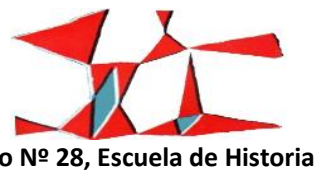

Facultad de Humanidades y Artes (Universidad Nacional de Rosario), 2016

pp. 39-68

ISSN 1853-8835 
No obstante estos lineamientos anti modernos, el catolicismo social permeaba los poros del mundo católico. En octubre de 1918 a fin de contestar las acusaciones que los sectores de libre pensamiento pertenecientes o simpatizantes de los estudiantes rebeldes realizaron al catolicismo durante todo el año y particularmente desde junio de 1918, la jerarquía católica de la diócesis de Córdoba convoca a todos sus integrantes al Primer Congreso Católico Diocesano que se lleva a cabo durante la segunda semana de octubre de ese año. Más allá de la enorme cantidad de gente de toda la provincia que acudió al llamado según LP, haciendo gala de un discurso hiperbólico, la demostración que cerró el congreso estuvo compuesta por 60.000 personas (aunque pensemos en un sexto de ese número, fue ciertamente un acto multitudinario ${ }^{21}$ )- lo que me parece más interesante es la reiterada invocación a la doctrina social de la iglesia que algunos congresales realizaron durante la distintas sesiones, apelando a León XIII y Pío X. La autocrítica que los dirigentes más encumbrados y diferentes delegados al Congreso realizaban por el alejamiento de los curas párrocos del pueblo y de la falta de hechos concretos que no solo alimentaran el alma, sino que se materializaran en asistencia mutua, recreación, creación de escuelas, etc. fue un tópico planteado en varias oportunidades. Por primera vez aparece con claridad en los discursos de estos hombres el concepto "Doctrina Social de la Iglesia" y el énfasis imperioso de llevarla a cabo para que el catolicismo pudiera convertirse en una alternativa a los grupos de izquierda que atraían al "pueblo", difamando y calumniando a la iglesia y sus representantes. Es probable que a pesar de todo el entusiasmo que la prensa transmitía sobre el éxito del Congreso, la mayoría de las ideas que allí se discutieron no pudieran consolidarse, sea por la fragmentación interna, por falta de recursos, por deficiente accionar militante. Posiblemente, este Congreso haya servido de estímulo a la formación de la Unión Católica Popular Argentina inaugurada al año siguiente. Monseñor Miguel de Andrea participó en los eventos de Córdoba. Pero la UPCA tampoco fue exitosa en esta ciudad y hasta costó demasiado trabajo conformarla orgánicamente, lo cual se produce años después de su fundación. ${ }^{22}$ Será recién en la década siguiente con la creación de la Acción Católica Argentina, cuando pareciera que las divisiones internas se canalizan, aunque no desaparecen del interior de la iglesia y el laicado católico.

Este Congreso, es solo un ejemplo para mostrar la tensión existente dentro del laicado, e incluso entre parte de este y la curia sobre las diferencias existentes respecto a la concepción que la iglesia -

\footnotetext{
${ }^{21}$ Conforme el Censo Nacional de 1914, la ciudad de Córdoba contaba con 134.935 habitantes.

${ }^{22}$ Vidal, Gardenia; “Intentos de centralización desde el Papado: La Unión Popular Católica Argentina en Córdoba”, en Gardenia Vidal y Jessica Blanco (comps.); Ferreyra Ed; Córdoba; 2010.
}

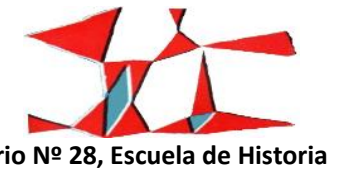


jerarquía y curas de base- debía mantener, particularmente, con los sectores populares. El avance arrollador que el movimiento reformista demostró en Córdoba, mediante discursos, la ocupación de las calles, la relación insistente con autoridades nacionales, los insultos frecuentes al clericalismo, etc., coadyuvó sin duda a que la "Doctrina Social de la Iglesia" apareciera con insistencia en esta gran manifestación, como no lo había hecho unos pocos meses antes, durante el Congreso Eucarístico Nacional que también se celebró en Córdoba replicando el encuentro principal en Buenos Aires. En esta ocasión, sobresalían las palabras Nación y Patria, pero en todo caso no fueron específicos de cómo encauzar las necesidades de la Nación. En cambio en octubre, el temor del avance de ideas anticlericales apremió a los católicos para adoptar, al menos una retórica popular que paulatinamente fue fortaleciendo las asociaciones asistenciales existentes e impulsando la creación de otras. ${ }^{23}$

\section{La dirigencia católica y los sectores subalternos}

Empero, pese a la discriminación clasista, los católicos liderados por integrantes de diferentes órdenes ${ }^{24}$, algunos sacerdotes auxiliados por laicos, no dejaron de preocuparse por la situación de los desamparados, aun antes de la Encíclica de León XIII como lo demuestra la creación de la Asociación de Artesanos de San José en la década del '70 del s. XIX, el Círculo Obrero en 1897, la Sociedad Católica Popular Italiana en 1911, la Asociación Protectora de la Sagrada Familia en 1921, los salesianos con su proyecto educativo iniciado en $1905^{25}$, por solo mencionar las instituciones locales -excepción del Círculomejor conocidas hasta ahora. ${ }^{26}$

\footnotetext{
${ }^{23}$ En la procesión de Corpus Christi de 1921, LP escribía lleno de euforia por otra muestra de unidad católica "Córdoba católica y creyente en la religión y fe de sus mayores está de parabienes porque ha sabido dar una categórica y concluyente prueba de esa fe y religión......demostrando que la elocuencia de los grandes actos colectivos, que la pretendida difusión de los ideales extraviados del liberalismo disolvente no es sino la más burda mistificación proselitista de la propaganda impía (...)La procesión magna del jueves lo ha evidenciado....¿¿qué reunión pública, qué acto colectivo para el que se cuente con los entusiasmos caldeados de la multitud, ha logrado congregar...un concurso tan numeroso y ponderado de la sociedad y el pueblo como el que nos fue dado presenciar...?" (LP 28-05-21). En la procesión de Corpus de 1918 la enemistad entre "liberales y católicos" se manifiesta en un editorial del diario: "(...) Anteayer, a poco de salir la procesión al pasar el S. D. M frente a dos jóvenes -tipo estudiantes- que con todo desparpajo, entre aquel maremágnum de creyentes, permanecían con el cigarrillo en la boca y los sombreros encasquetados se les acercó el maestro de ceremonia y con cortesía les insinuó el deber de descubrirse a lo que contestaron en forma inculta negativamente". Luego de una larga argumentación LP termina la nota señalando que la liberta no consiste en hacer lo que se quiere, sino lo que se debe..." (LP 01-06-18). Reacciones parecidas se observan en la prensa en años venideros.

${ }^{24}$ No sabemos la relación que estos tuvieron con la curia en el momento de tomar estas decisiones.

${ }^{25}$ Sobre los Salesianos en Córdoba se puede consultar: Moretti, Nicolás D.; Buenos cristianos y honrados ciudadanos. La obra salesiana y la cuestión social. Córdoba, 1905-1930; Centro de estudios Históricos; Córdoba; 2014.

${ }^{26}$ La SCPI ya había sido creada en Buenos Aires el año anterior, pero no conocemos una agrupación similar en alguna otra provincia.
}

51

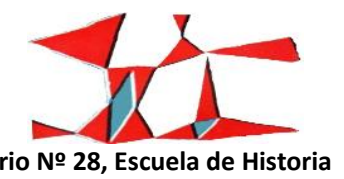

Facultad de Humanidades y Artes (Universidad Nacional de Rosario), 2016

pp. 39-68

ISSN 1853-8835 
La instalación del capitalismo en la nueva división mundial del trabajo en Argentina, la llegada de tantos inmigrantes de ultramar y la migración interna, por consiguiente el avance demográfico y, sobre todo, el desarrollo de la organización gremial y de los grupos de izquierda en Europa, además del desarrollo y avance del concepto de caridad cristiana estimularon y acecharon a muchos católicos para comenzar a organizar a los hombres y mujeres más olvidados de la sociedad, mediante algún tipo de asistencialismo y por supuesto de formarlos en la doctrina católica. En este sentido, encontramos presbíteros como Hilario Fernández, Conrado Vizcarro, Pablo Cabrera, entre otros y laicos como los ya mencionados, igualmente algunos pertenecientes a la actividad comercial como Marcos Argüello, Eusebio Deanquín, José Pastorino, Pedro Moreira... o trabajadores (urbanos o rurales): Ramón Sánchez, Domingo della Vedova, Pedro de la Vega, Ernesto Opovín, Natividad Fernández, entre muchos otros que fueron los artífices de las organizaciones católicas para trabajadores. ${ }^{27}$

Por lo tanto, como dije más arriba, los católicos enfrentaron a los "reformistas" adueñándose también ellos de las calles como lo ponen de manifiesto las innumerables procesiones masivas que tuvieron lugar, en particular desde julio de $1916 .^{28}$

\section{La Asociación de Artesanos de San José}

Esta asociación (AASJ) tiene sus orígenes en la Asociación de Obreros Católicos fundada en 1877 por el jesuita R. P. Cayetano María Carlucci. Al ser instituida bajo la advocación de San José, sus integrantes pasaron rápidamente a ser conocidos como Josefinos; cuando en 1882 el mismo sacerdote crea la rama femenina, sus socias serán denominadas Josefinas. Según indicaba uno de sus socios protectores, Luis Santillán Vélez, la institución se había constituido como una cofradía ${ }^{29}$ con el objeto de desarrollar prácticas

27 En cuanto a los datos sobre los protagonistas que participaron de las asociaciones católicas consultar Vidal Gardenia (directora), Reseña biográfica de dirigentes que interpelaron el mundo del trabajo en Córdoba 1900-1950, 2014, http://www.ffyh.unc.edu.ar/sites/default/files/ebooks/ EBOOK_RESENABIOGRAFICA.pdf

28 Se relevaron las procesiones de Corpus Christi de los años 1918, 1921, 1925, 1928, 1929 y 1930 y las manifestaciones de Rogativas Pública (con la imagen de la Virgen del Milagro), 08-10-16; Primera Comunión de la Obre de la Doctrina Cristina, 22-07-17; Festividad de la Virgen de Lourdes, 26-08-17; Virgen del Carmen, 16-07-28 y 30; San Roque, 19-08-28 y 24-08-30, la Procesión de María Auxiliadora, 24-05-30. Además de las dos mencionadas en el texto de 1916. La fuente utilizada para todas ellas ha sido el diario Los Principios.

${ }^{29}$ Las cofradías o hermandades, como también se las denominaba en la colonia, eran asociaciones de fieles que tenían objetivos diversos, fundamentalmente, religiosos y espirituales. Algunas también se preocupaban por el bienestar material de sus socios: ayuda mutua, asistencia a los huérfanos, los enfermos, etc., Di Stefano, R; Sabato, Hilda; Romero, L. y Moreno, J; De las cofradías a las organizaciones de la sociedad civil. Historia de la iniciativa asociativa en Argentina; Edilab; Buenos Aires; $2002 ;$ pp. 33-41.

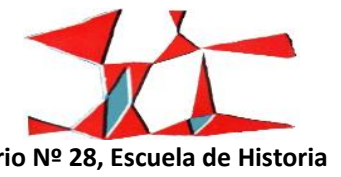


religiosas y asistir por medio de la constitución de "bazares" a algunas demandas básicas de sus socios. Sin embargo, el avance de las ideas socialistas y "aún anarquistas" entre los trabajadores de Argentina convencieron a los directores de procurar "no solo el mejoramiento moral de los obreros, sino también material". De ese modo, la original cofradía se transformó en una sociedad de socorros mutuos, probablemente en 1904. Entre los cambios notables figuraban el otorgamiento de subsidios médicos y remedios en caso de enfermedad, facilidades para gastos de casamiento, así como servicio fúnebre para los pobres. Sin embargo, la oferta más atractiva para los socios fue la posibilidad de convertirse en propietario de un terreno y, eventualmente, de una casa "higiénica, cómoda y sana", que sustituiría el rancho donde vivían hacinados. Esta iniciativa, acorde a Los Principios, había sido del director de la asociación R. P. Hilario Fernández, quien la había puesto en marcha con fondos propios, al tiempo que motivaba a miembros de la élite católica para sistematizar un proyecto a largo plazo. Por consiguiente, en 1904 se crea la Asociación Protectora de Artesanos de San José, organismo integrado por los sectores más acomodados de la ciudad que dedicará sus esfuerzos exclusivamente a la adquisición de terrenos -mediante préstamos y donaciones particulares y oficiales- para comprar lotes y construir viviendas "dignas" para los socios ${ }^{30}$. Unos años después, en 1912, la AASJ renueva nuevamente sus estatutos, esta vez con el propósito de solicitar la personería jurídica, la cual obtiene ese mismo años; desde entonces sus actividades se diversifican aún más y se organizará como una asociación representativa de tipo indirecto regida por una Junta Ejecutiva. Empero las decisiones más trascendentales, incluso las que involucraban actuaciones menores, eran tomadas por el Director, cargo que recaía siempre en manos de un jesuita. Esta entidad fue respaldada y hasta confundida con las congregaciones josefinas originales.

Desde un comienzo la relación más estrecha que se estableció entre sus autoridades y los socios fue a través de conferencias desarrolladas generalmente por jesuitas en espacios que permitían la concentración de un número elevado de personas. Los oradores eran sumamente didácticos al transmitir las ideas a un público analfabeto o escasamente alfabetizado: un abstracto mensaje teológico lo convertían en asequible para el entendimiento de esos grupos. De esa manera, se fortalecía la instrucción de los trabajadores y desempleados quienes internalizaban un dogma católico más complejo, facilitando así su

\footnotetext{
${ }^{30}$ Sobre esta asociación, consultar Boixados, Cristina; “Vivienda y moral. La acción de la Comisión Protectora de los Artesanos de San José, 1900-1930" en G. Vidal y P. Vagliente (comps.) Por la Señal de la Cruz. Estudios sobre la Iglesia Católica y sociedad en Córdoba, S. XVII-XX; Ferreyra Ed.; Córdoba, 2002.
}

53

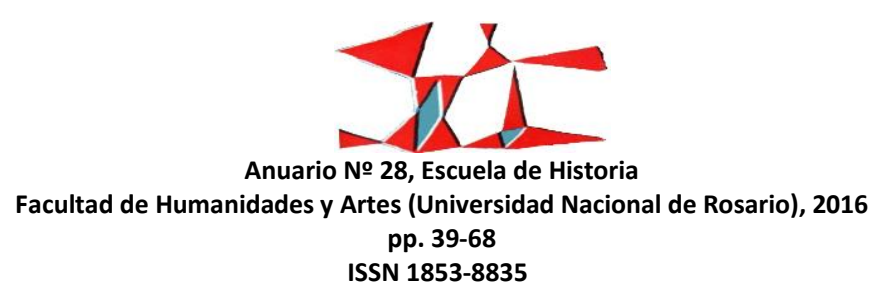


formación religiosa y la cooptación de hombres y mujeres que podrían ser atraídos -al estar en "disponibilidad"- por una ideología absolutamente opuesta a la de izquierda. Con el tiempo, a la obligación de los socios de asistir a las conferencias, que pretendían "regenerar al obrero", se sumó la exigencia de la comunión mensual, tanto de adultos como de niños, las visitas a las cárceles para el reparto de pan, ropa, cigarrillos; el desarrollo de ejercicios espirituales; la participación en las fiestas de San José...

Según Pablo Vagliente, el público que acudió a la primera conferencia era sociológicamente heterogéneo: "El honrado y laborioso artesano, el padre de familia, el jornalero, el regularmente acomodado, el pobre, el instruido y el que no lo era" ${ }^{31}$, rasgo que en general no cambia sustancialmente en los años venideros. El número de socios fue importante desde sus inicios, conforme a algunos autores, la asociación logró reunir entre 400 a 600 personas en la década de $1870^{32}$. Al comenzar el s. XX este número tiende a aumentar ${ }^{33}$. De todos modos, es posible que la cantidad de afiliados haya descendido hacia fines de la década del veinte, aunque, por el momento, no pueda inferir las razones, más allá de la distribución de personas que se debe de haber producido entre las diferentes asociaciones mutuales existentes en la ciudad $^{34}$.

A comienzos de ese siglo, podían registrarse como socios los hombres de entre $15^{35}$ y 50 años que estuvieran dispuestos a cumplir con los estatutos "basados en los principios de la más sana moral y de nuestra santa religión". Al menos, desde los primeros años de la nueva centuria, la Junta Directiva estaba conformaba por hombres que no provenían de la élite, a modo de ejemplo la de 1908 la integraban mayoritariamente artesanos como Clodomiro Faccio, Francisco Capelli, Eusebio Deanquín, nombres que a

\footnotetext{
${ }^{31}$ Vagliente, Pablo; "Sociedad civil. Cultura política y debilidad democrática en Argentina: explicando el colapso constitucional desde el caso Córdoba, 1850-1930"; Tesis de Doctorado, Facultad de filosofía y Humanidades; Universidad Nacional de Córdoba; 2010; p. 250

32 Chaves, Liliana; Tradiciones y Rupturas de la Élite Política Cordobesa (1870-1880). La clave conservadora de la modernización política; Ferreyra Ed.; Córdoba; 1997; pp. 205-207. Vagliente, Pablo; "Sociedad civil. Cultura política y debilidad democrática en Argentina: explicando el colapso constitucional desde el caso Córdoba, 1850-1930" Tesis de Doctorado; Facultad de filosofía y Humanidades; Universidad Nacional de Córdoba; 2010; pp. 250-252

${ }^{33}$ LP 01-08-04; 19-03-05; 08-10-05. A fines de 1905, el diario señala que los socios han aumentado a 1.500, "pudiendo calcularse en 900 los que comulgan con regularidad" (LP 22-11-05). Como la comunión mensual era obligatoria para los socios, era frecuente que siempre se refirieran a ella para considerar el número efectivo de adherentes. Sin embargo, en la década del '10 desaparece este tipo de datos de la prensa, solo en algunas oportunidades se refiere a la "numerosa asistencia" de socios.

${ }^{34}$ En 1929, se indica que en la comunión general "comulgaron más de cien socios" (LP 23-04-29), dato que muestra una baja notable de comuniones en comparación con 1905.

35 Los menores de 15 años formaban una sección especial. Estatutos de la ACASJ aprobados el 17 de marzo de 1912, Art. $4^{\circ}$, Inc. A.
}

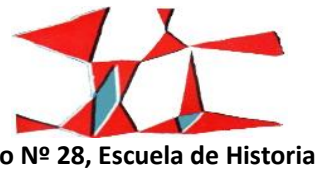

Facultad de Humanidades y Artes (Universidad Nacional de Rosario), 2016

pp. 39-68

ISSN 1853-8835 
su vez se repiten en las comisiones directivas del Círculo Obrero. Lo mismo sucede en 1916 y 1917 cuando la presidencia es ocupada por Rosendo Gigena (mayordomo del Colegio Monserrat).

De acuerdo a los estatutos de la AASJ, la elección de los miembros de la JD era anual; se producía en asamblea de socios reunida "el domingo después de la octava del Patronato de San José" y podían asistir a ella los socios varones "en cuenta corriente presentando la libreta de pago", es decir los que estuvieran al día con el pago de las cuotas ${ }^{36}$. Un mes antes, la JD designaba una comisión de seis miembros presidido por el director con el fin de seleccionar una lista de seis socios para poner a consideración de la asamblea general, la cual solo tenía derecho a elegir de entre ese número al presidente y vicepresidente; los cuatro nombres restantes juntamente con el director, el presidente y el vicepresidente recientemente electos designaban a los demás integrantes de la JD. O sea que la función electora de los socios asistentes a la asamblea se limitaba a solo dos miembros de la $J^{37}$. En esos encuentros, más allá de llevar a cabo los comicios se discutían otros temas, de "importancia para la institución"; aunque es difícil conocer los asuntos debatidos, dado que en las actas solo se transcribe la lectura de la situación financiera y el resultado de los $\operatorname{comicios}^{38}$.

Al iniciarse el siglo, la AASJ estaba organizada en cinco secciones que se fueron incrementando con el correr del tiempo: en 1921 ya existían trece con sus respectivas autoridades. Cada una de las secciones era regida por un consejo compuesto por el número de miembros que la JD estipulaba, organismo que a su vez elegía a sus integrantes, quienes también pasaban a formar parte de la JD. Las nuevas autoridades electas eran proclamadas el tercer domingo del mes, día en que se oficiaba la misa y la comunión general obligatorias. Después de la celebración religiosa, se reunían en la Plazoleta de la Compañía de Jesús (frente a la iglesia del mismo nombre), donde el R. P. Superior de la Orden entregaba los títulos que los hacían acreedores de su nueva función, demostración simbólica del poder adquirido por estos individuos.

Si bien cada sección tenía una autonomía relativa, por ejemplo, admitir socios provisoriamente, designar comisiones, expulsar afiliados, todas sus acciones debían ser avaladas por la JD. Otro integrante importante dentro de este organigrama era la figura del celador (podía haber más de uno), quien debía preocuparse por conocer el estado de los enfermos, visitarlos, inscribir a los nuevos socios, militar para

\footnotetext{
${ }^{36} \mathrm{LP}$ 15-05-27.

${ }^{37}$ Estatutos de la Asociación Católica de Artesanos de San José, 1912, Art. 17; LP 11-04-22.

38 LP 23-05-29.
}

55

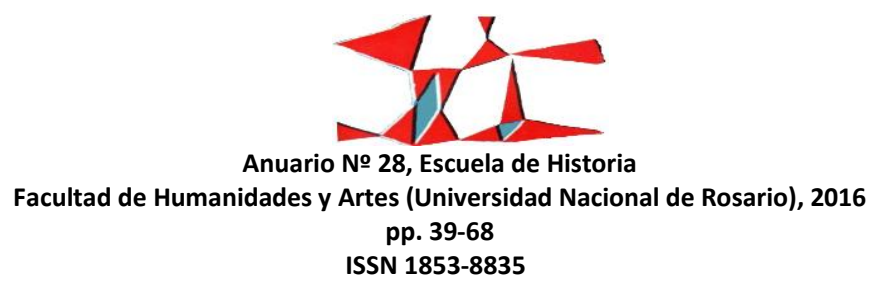


aumentar el número de adherentes, autorizar el pago de subsidios, registrar cambios de domicilio, comunicar los días de reunión y las resoluciones de la JD, asistir a los actos públicos y piadosos... En definitiva, los celadores constituían el eslabón más importante de mediación entre las autoridades y la gente. En el siglo XX, el director que más se destacó por el trabajo desempeñado y el lugar que ocupaba en el imaginario de la institución y de la prensa católica fue el jesuita R. P. Hilario Fernández director en la década del diez, designado como todos por el Superior de la Orden. Los Principios opinaba sobre él que "se ha dado cuenta exacta de que los obreros a[de]más de las prácticas religiosas, [necesitan] un mejoramiento de sus condiciones de vida" y por esa razón se preocupaba, como ya se dijo, por construir casas cómodas e higiénicas para los trabajadores, una escuela nocturna para "obreros" -sumada al ya existente y "concurridísimo" Colegio San José diurno, fundado en 1881-, el panteón para los socios, la protección de los afiliados enfermos o desempleados mediante subsidios.

Los Josefinos celebraban dos fiestas anuales: el día de San José -19 de marzo- y el de su Patrocinio. El análisis de estos eventos refleja una cantidad considerable de hechos que atravesaban la vida de los adherentes, creando lazos diversos y claras acciones de militancia. Desde el fomento de los vínculos de sociabilidad internos hasta las relaciones que establecían con las demás asociaciones católicas, así como la participación comprometida en cada una de estas fiestas.

El día de San José era día laborable por lo que los católicos lo denominaban semifestivo, aunque con el tiempo, la Santa Sede exigió que se declarara feriado. La celebración de esta fecha consistía en un novenario que culminaba el 19 de marzo con una misa de comunión obligatoria llevada a cabo con cantos piadosos a la mañana temprano, que implicaba para aquellos que la realizaban la indulgencia plenaria. Posteriormente, los socios hombres pasaban a desayunar al salón social. En ocasiones, se rifaban diversos objetos entre los cuales solía haber uno preponderante: un lote cedido por la Comisión Protectora; a veces la rifa se realizaba solo entre los socios que más se habían distinguido por su caridad con los enfermos, el número de adhesiones que habían logrado o por los ahorros que habían realizado en vista de comprar un terreno o casa, y siempre se les regalaba una estampa del santo con las indulgencias "con que está enriquecida la Congregación". En ocasiones, esta fiesta se celebraba con la concurrencia de otras asociaciones que también estaban bajo el patrocinio de San José y se aprovechaba para demostrar algún progreso importante de la institución como en 1912, cuando se inauguró el salón social. Desde mediados




de la década del '10 la procesión más importante se realizaba en el "Barrio de los Josefinos" 39 en Nueva Córdoba. A la tarde asistían los socios/as de toda la ciudad y todos aquellos que se sintieran identificado con el catolicismo; se iniciaba la procesión desde la casa de uno de los adherentes donde se había estado desarrollando el novenario los días previos y se guardaba la imagen del santo y de la virgen de Lourdes, imagen con la que se identificaba a las Josefinas. Una de las demostraciones más notorias fue la celebrada en el año 1921, a la que asistieron numerosas personas provenientes de otros barrios de la ciudad. La procesión partió, como era habitual de la casa del socio Ramón Gallardo Ibañez en cuya casa se guardaban las imágenes y donde "se había levantado un artístico altar". La numerosa concurrencia a la novena se repitió y la procesión fue acompañada por la banda de Música de la Provincia; la multitud recorrió las manzanas del barrio de los Josefinos "en medio del mayor entusiasmo y de cánticos religiosos". En distintas viviendas se habían levantado altares para rendir culto al santo y a la Virgen de Lourdes. En el altar de la casa de los jóvenes Guzmán y Barraza, Manuel Maciel -respetado católico social, maestro y redactor en el diario Los Principios- pronunció un discurso; también hablaron los padres capuchinos, Moisés Dávila superior de la Orden de los Jesuitas- y Conrado Vizcarro, director espiritual de la asociación. Al finalizar la procesión y luego de dejar las imágenes nuevamente en la casa del vecino lbañez, un cura en representación de la UPCA y otra vez Manuel Maciel volvieron a pronunciar arengas; asimismo varios niños hicieron gala con declamaciones. A la noche se llevó a cabo una velada, donde por tercera vez en el día se oyeron las palabras de Manuel Maciel, disertando sobre temas religiosos y sociales ${ }^{40}$. En pocas ocasiones esta fiesta era coronada por algún programa de entretenimiento, no obstante, las veces que eso ocurría la oferta era siempre del estilo de los entretenimientos de la época. ${ }^{41}$

La fiesta del Patrocinio de San José se realizaba en una fecha fija y, probablemente, dependía del calendario cuaresmal, no obstante en general se conmemoraba a fines de abril o principios de mayo y en este caso su trascendencia socio-simbólica se manifestaba al instituirlo como día feriado. A los rituales típicos consistentes en celebración de misas, comunión obligatoria (que tenía valía pascual), servicio de desayuno para los socios varones, en algunas ocasiones se programaba algún tipo de juego como "el de

39 Se lo denominaba así porque se habían distribuido varios lotes y construido casas para ellos con un terreno cedido por la provincia.

${ }^{40}$ LP 21-03-21.

${ }^{41}$ Por ejemplo el espectáculo de 1918, cuya entrada costaba 0,20 ctvs., se componía de los siguientes ítems: Vals; "Dos palabras" recitado por un socio, Mazurca, el drama en cuatro actos "Los dos sargentos" (cada acto lo intercalaban con las otras propuestas), Two Step (sic), Marcha, Vals, Mazurka, "Un criado de dos amos" -sainete en dos actos- y Marcha Final.

57

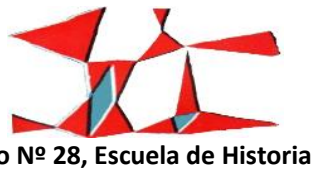

Facultad de Humanidades y Artes (Universidad Nacional de Rosario), 2016

pp. 39-68

ISSN 1853-8835 
pelota", se les informaba sobre cuestiones puntuales de la institución y se celebraba una procesión a la tarde. En otros casos, luego del desayuno se llevaba a los socios a ver los terrenos o casas administrados por la Asociación Protectora en los distintos barrios de la ciudad: Pueblo Nuevo, San Martín, General Paz, San Vicente y por supuesto, Nueva Córdoba ${ }^{42}$. A veces se rifaba, como en la fiesta del 19 de marzo, premios sumamente importantes como el atractivo terreno. Pero lo más interesante de esta celebración religiosa era la preparación previa de los socios: asistir a diversas conferencias dictadas principalmente por sacerdotes, pero también por laicos sobre asuntos que pretendían adoctrinar no solo al fiel religioso, sino al trabajador en la doctrina católica. Por ejemplo en el año 1904, la JD decidió "solemnizar más ese día" mediante la información de dos puntos: a) perdonar todas las cuentas atrasadas de los socios en la medida que se presentasen dentro del mes siguiente a arreglar su situación, b) conceder el título de socio activo a todo aquel que perteneciera a sociedades análogas y solicitara ser miembro de la AASJ, sin necesidad de pagar el derecho de ingreso, ni esperar para gozar de los beneficios que se distribuían a los socios; el único requerimiento era "mantener vivo el espíritu católico en el individuo, la familia y la sociedad" ${ }^{43}$. El Círculo Obrero de Córdoba estimuló inmediatamente a sus afiliados para que se adhirieran a la AASJ.

En un comienzo, las conferencias se extendían durante aproximadamente una semana, luego se redujeron a tres días y se daban al final de la tarde con el propósito de que los trabajadores pudieran asistir luego de haber terminado su rutina laboral. Las disertaciones, como se decía explícitamente, se realizaban para preparar a los obreros, empleados y artesanos para la fiesta del patrocinio y también para el cumplimiento pascual de aquellos que todavía no lo habían efectuado. Las mismas podían ser presenciadas por todos los trabajadores fueran o no socios. En algunas se trataban temas directamente relacionados con los derechos del trabajador como el descanso dominical, la huelga, el ahorro, entre otros. En general, los dos tópicos más comunes eran la glorificación de la figura modélica de San José y los beneficios que traería en la vida de cada uno su imitación, así como la descalificación de las opciones políticas de izquierda. En un artículo publicado por LP bajo el título La Fiesta de los Obreros, se indicaba: “...no nos referimos a la fiesta del $1^{\circ}$ de mayo que se ha dado en llamar la fiesta de los trabajadores y que un puñado de inconscientes ha celebrado en Córdoba, paseando por las calles la bandera roja del socialismo, sino a la que el domingo

\footnotetext{
42 LP 14-05-05.

${ }^{43}$ En el individuo, manteniendo una vida morigerada y laboriosa, en la familia con el cumplimiento de los deberes domésticos respectivos a cada uno, y finalmente en la sociedad dando el buen ejemplo y mostrándose fiel a sus obligaciones como católico y ciudadano. LP 17-04-04.
} 
pasado se celebrara en conmemoración de un obrero que en su escuela y en su taller tuvo a otro obrero cuya doctrina y cuyo ejemplo supieron dignificar como nadie el trabajo y las clases trabajadoras. Nos referimos a la fiesta de San José que los obreros cristianos de Córdoba han celebrado anteayer en la actitud pacífica de los que tienen conciencia de sus destinos, de los que entienden que piedad y trabajo honrado son los dos brazos con que se llega a la posesión del bienestar y de la posible felicidad. El Círculo Obrero de Córdoba y la Asociación Católicos Unidos por el vínculo de una misma fe y de un mismo ideal se dieron cita para honrar (...) al panteón de los obreros cristianos en la capilla del Colegio Pío X donde tuvimos ocasión de escuchar las más sabias [palabras]. [Esas asociaciones] y los Artesanos de San José que tantos obreros cuenta en sus filas han celebrado la fiesta de San José. Sin bandera roja y sin el toque de la internacional socialista, la fiesta del domingo ha sido verdaderamente la fiesta del trabajo y el día de los trabajadores. [Además, este años también se dio la misa en italiano] lo cual significó que hubiera colonos que diariamente después de haber trabajado todo el día acudían a la capilla anexa al Colegio Pío X (Salesiano) desde 5, 6 y 10 $\mathrm{Km}$ de distancia para escuchar la autorizada palabra del P. Adalberto Pasionista. Se encontraron allí personas que, según ellos, hacía 5, 10 y hasta 20 años que no habían frecuentado iglesia alguna por no encontrar lo que les podía satisfacer..." ${ }^{44}$.

A comienzos de la década del veinte y como demostración del crecimiento de la AASJ, comenzó a festejarse el día del Patrocinio también en Barrio Alta Córdoba. Allí los josefinos fueron contenidos por los misioneros del Corazón de María en la parroquia del mismo nombre, donde funcionaban otras asociaciones como la Juventud Católica. Esta última estaba compuesta por estudiantes y empleados y era contemporánea de otras organizaciones juveniles que surgieron hacia 1918 con el fin de contrarrestar las propuestas reformistas. Desde entonces desarrolló un papel significativo en la composición del "público" católico contrario a los defensores de la Reforma Universitaria y probablemente también se ocupó de otros asuntos que no hemos podido descifrar por el momento. Lo cierto es que en Alta Córdoba aparece como una organización consolidada a principios de la década del veinte y actúa en estrecha relación con los Josefinos. De allí que LP sostenga, refiriéndose a la fiesta de 1924, que "Ellos [los jóvenes] darán la nota alegre de los sanos y eficaces entusiasmos" ${ }^{45}$. Desde entonces el festejo del Patrocinio en esa barriada se sumó a las llevadas a cabo en la Compañía de Jesús. Por ejemplo en 1924, el diario informa sobre las

\footnotetext{
44 LP 05-05-14.

45 LP 11-05-24.
}

59

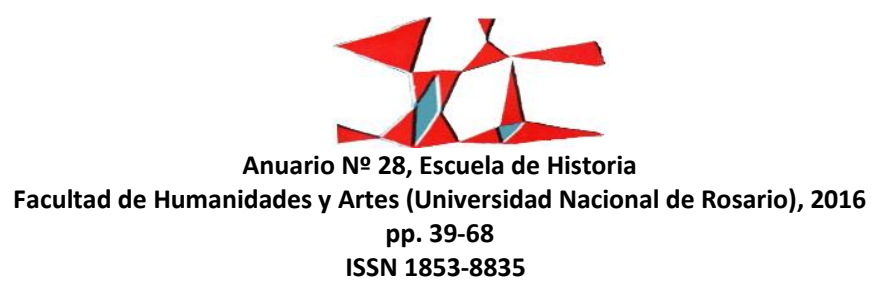


diferentes misas que se pronunciarían en aquel barrio y exhortaba a la comunión general reglamentaria para todos los socios, hombres y mujeres. Asimismo, menciona que después de la última misa de la mañana se bendeciría la bandera que acababan de adquirir para la "Sociedad Obreros Josefinos". Al acto asistirían especialmente los invitados, todas las asociaciones católicas que decidieran hacerlo y, por supuesto, los socios y socias de la zona. El gobernador eclesiástico de la diócesis, Monseñor José A. Luque, presidiría el acto que se realizaría, en el Colegio de los padres del Corazón de María y en su templo parroquial ${ }^{46}$. A estas celebraciones acudían los centros católicos de hombres y mujeres, cofradías, asociaciones obreras y escuelas de la localidad que formaban "una larga y nutrida columna acompañando al santo". En 1923 la presencia de representantes de la UPCA fue cuantiosa así como los discursos de sus miembros ${ }^{47}$. Hacia fines de esta década, la festividad de San José ya se celebraba en varias iglesias de la ciudad, no se debe olvidar que el "Padre de la Sagrada Familia" ya hacía unos años había sido designado Patrono de la Iglesia Universal.

En 1919, la prensa remarca la trascendencia que había tenido una de las conferencias, previas a la fiesta principal que se realizó en el Paseo Sobremonte, frente a la sede del Círculo Católico; ese festejo coincidía con el aniversario de la Encíclica Rerum Novarum, motivo por el cual los militantes se esforzaron con sus tareas para que el evento fuera trascendente para la ciudad. Más allá de los rituales habituales, a las 20 hs. se realizó un encuentro en esa plaza adonde acudieron no solo los josefinos y josefinas, sino también los socios del Círculo Obrero y los de la Sociedad Católica Popular Italiana (relacionada con los salesianos). La concurrencia, según la misma fuente, superó las 1000 personas y "los vivas al catolicismo y a la clase trabajadora fueron entusiastas, demostrándose "el anhelo palpitante por la sanción de las leyes que han levantado como plataforma social los núcleos católicos cordobeses". En la demostración, el estudiante Carlos R. Melo leyó la nota que enviarían a la Legislatura por iniciativa del Círculo, pidiendo la sanción de las leyes protectoras del trabajo y de mejoras del "proletariado", aclamada por los presentes. Cabe señalar que en Buenos Aires, las autoridades de los Círculos Obreros ya hacía varios años que presionaban al Congreso para que sancionara los proyectos de leyes en beneficio de los trabajadores, incluso en octubre de 1913,

\footnotetext{
${ }^{46}$ LP 23-03-24.

${ }^{47}$ Entre los que se destacaron el Sr, Manuel Augusto Ferrer, Sr. Jacinto Ortiz de Guinea y también el obispo diocesano, asesor de la UPCA, Iltro. Obispo Inocencia Dávila Hablaron respectivamente de "las causas del malestar social y las diferentes propuestas de las diversas escuelas sociales y económicas"; "de la organización y finalidades de la UPCA"; y finalmente el obispo "instó a los católicos a adherirse a dicha institución" LP 23-04-23.
} 
convocaron a una manifestación frente al Congreso de la Nación a fin de ejercer presión sobre los legisladores ${ }^{48}$. La nota de referencia decía: "El Círculo Obrero de Córdoba cumpliendo uno de los fines primordiales de la institución que era procurar la mejora en las condiciones de trabajo y de vida de las clases proletarias, tiene el agrado de dirigirse a V. H., solicitándole medidas de legislación, que tiendan a establecer la jornada máxima de ocho horas, el salario mínimo, y a procurar el abaratamiento de la vida".

Luego los firmantes pasaban a sintetizar las razones de cada uno de los pedidos, coincidiendo esta actitud con la política laboral desarrollada por los Círculos Obreros de Buenos Aires desde hacía varios años y también con las disposiciones de "acercarse al pueblo" definidas por el Primer Congreso Católico Diocesano de Córdoba (octubre 1918). La defensa de la jornada de ocho horas la realizaban en base a lo que ocurría en otros países "civilizados" donde ya estaba implementada, en particular en Italia "merced al requerimiento y campaña decidida de los sindicatos católicos". Las jornadas de labor tan extensas no solo destruyen en el cuerpo en un tiempo corto, sino que "embrutece[n] y materializa[n] el alma". En cuanto al salario, recompensa del trabajo que permite la producción, no solo es ínfimo respecto al otro elemento indispensable de la misma "el capital", sino que es insuficiente para "satisfacer las exigencias materiales y morales de la vida". El salario debe representar al menos la cantidad necesaria para la sobrevivencia. "Lo imponen la ley natural y los principios elementales de la justicia consignados magistralmente en la encíclica del inmortal León XIII Rerum Novarum. Y por fin, insistían en trabajar para el abaratamiento de la vida, en particular terminando con los trusts de alimentos (especialmente el de la carne, lucha que motivará unos años después una gran rebelión social que estará liderada no solo por los grupos de izquierda, sino también por el Círculo de Obreros) ${ }^{49}$.

\footnotetext{
48 "Solicitud a la Legislatura en favor del obrero", El Trabajo (periódico de los Círculos), octubre 1913.

49 El encarecimiento desproporcionado de la vida, en relación a la limitada alza de los salarios radicaba en tres órdenes de necesidades sostenía la nota: el alimento, los vestidos y la vivienda de los obreros. Una forma de abaratar los alimentos sería suprimiendo los impuestos que gravan los artículos de consumo y destruir los trusts y monopolios que tienden a encarecerlos. La cuestión relativa a los artículos de vestir, si bien radicaba sobre todo en la regulación del régimen aduanero a cargo de la nación, podría tratarse dentro de las atribuciones de la provincia, fomentando las industrias que los produjeran en condiciones ventajosas y fijando precios máximos por medio de juntas de subsistencias como lo hacen varias naciones europeas y americanas tanto para los artículos alimenticios o de vestir (LP 13-05-19).
}

61

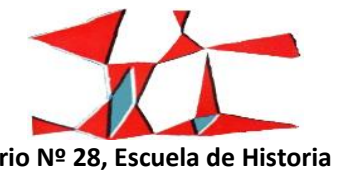

Facultad de Humanidades y Artes (Universidad Nacional de Rosario), 2016

pp. 39-68

ISSN 1853-8835 
Estos son los términos de la petición -suscripta por las autoridades del Círculo- que enviarían a la legislatura ante una multitud entusiasta afiliada a diversas asociaciones católicas o independientes, que aplaudía y vivaba sin $\operatorname{ces}^{50}$.

\section{Los Principios y la retórica sobre San José}

Lo que me interesa reconstruir brevemente es la retórica que el diario utiliza para referirse al San José modélico y, por ende, a quienes todos -en particular los trabajadores- debían imitar: los hombres para seguir su ejemplo al pie de la letra y las mujeres para encontrar un esposo con esas características. Entre las virtudes que más remarcaba con ejemplos y diciéndolo explícitamente se destaca la obediencia de José y todo lo que de ella pueda derivar: trabajo, pobreza, alegría... "El ejemplo glorioso del artesano que merece tener en su taller por oficial al Hijo de dios está llamado a ejercer una influencia poderosa en la cuestión social: en la casa de Nazaret no había riquezas, sin embargo, había felicidad y había trabajo, no obstante no había descontento; en consecuencia ni la riqueza engendra la felicidad, ni el trabajo la desgracia, hay que buscar en la virtud la paz del hogar. Todo aquel obrero que imite a San José conseguirá hacer su santuario [en] un pequeño taller donde reine Jesucristo, como acontece en Nazaret" ${ }^{\prime 51}$. Sin embargo, este asentimiento de la pasividad del santo como se advierte más arriba, no es antagónico con solicitudes sobre la defensa de los derechos de los trabajadores como cuando piden la jornada de 8 hs, por ejemplo, porque un desempeño tan extendido arruinaba el cuerpo. Simbólicamente, la Sagrada Familia fue representada en una escultura en su vida ordinaria de hogar, o sea trabajando; San José y el Niño están aserrando madera y la Virgen hilando. La insistencia en el beneficio del trabajo es constante y ese escenario artístico desmiente a aquellos que sostienen que el trabajo degrada como a aquellos que afirman que la religión es enemiga del progreso y favorece el ocio $^{52}$. Contrariamente subraya la modestia de José y la elección que hizo la Providencia para que sea padre de Jesús; de allí que Los Principios insiste en que no todos "podemos ser potentados, ni generales, ni ministros, ni ricos, ni buenos escritores, ni aún caciques de una pequeña localidad; la inmensa mayoría de los hombres está destinada a vivir en la modestia y la obscuridad"53; de esos sectores había sido elegido el padre de la Sagrada Familia. Sin embargo, cuando reconstruye la historia

\footnotetext{
50 LP 13-05-19

51 LP 02-03-06

52 LP 22-04-09

${ }^{53}$ LP 10-03-27
} 
familiar de José a través de los dichos del Evangelio, la inicia con la narración de la existencia de antecesores poderosos y destacados como gobernantes de las tribus de entonces, que en la práctica implicaba poder y reconocimiento del resto de la población hacia ellos. Eso se fue perdiendo y en el momento de la llegada de Jesús, José a través de su "mansedumbre, bondad, paciencia, modestia, paz y serenidad de corazón" brillaba "no con (...) el renombre de un científico, ni el poder avasallador de la elocuencia, ni el prestigio de ruidosas hazañas que pregona la fama" ${ }^{\prime 54}$, sino con la honrada labor de sus manos -como artesano, como carpintero- con la cual pudo mantener al Niño y a María.

El Evangelio solo dice que José fue un varón justo, no dice ni cuando nació ni cuándo murió, pero se induce que ya estaba muerto en el momento de la Pasión de Cristo ${ }^{55}$.

En síntesis, el diario rescata de José las virtudes que quiere transmitir al resto de los hombres, en particular a los que tienen menores recursos, pero no olvida que los poderosos, ricos, políticos, también existían en Israel y que muchos años atrás, José había pertenecido a una familia de ese tipo. No indica los sucesos por los cuales dejó de corresponder a ese sector social, allí se produce un hiato desvalorizado, que solo sirve de causa para mostrar al San José contemporáneo a la llegada del Mesías que acepta cumplir el rol de padre y esposo indicado por la Providencia. Por consiguiente, no solo es patrono de los trabajadores, modelo y protector de las familias cristiana, sino también de los jóvenes y las doncellas "porque amparó y cuidó como solícito jardinero la flor más bella de los jardines celestiales, la Inmaculada Virgen María"56

\section{Consideraciones finales}

La narración anterior nos permite realizar varias consideraciones relativas al objeto que me propuse. La formación del "nuevo catolicismo" en Córdoba es lento y de cariz moderado. Durante varias decenas de años no desapareció de su seno una dirigencia francamente integrista y notabiliar que no hubiera dudado en suscribir, al menos, partes del Syllabus. En este trabajo observamos esa actitud en particular en referencia a la política y los conceptos de democracia, ciudadanía, partidos políticos, competitividad electoral, etc. La presencia de una dirigencia católica "aristocratizante" continuó exponiendo sus ideas hasta fines de la década del '20. En la del treinta, parte de ella se adhirió a la Unión Nacionalista de

${ }^{54}$ LP 19-03-20

55 LP 10-03-27

${ }^{56}$ LP $19-03-19$

63

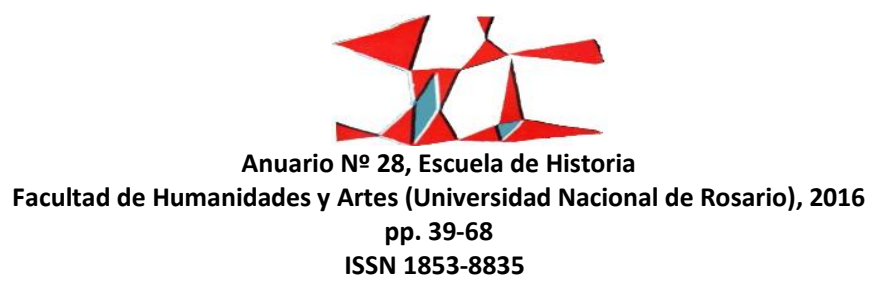


Córdoba (alineada con el fascismo y liderada por Eusebio Deanquín), a la cual, incluso, se adhirieron autoridades del Círculo Católico de Obreros y de los Josefinos. No obstante, las disidencias que este grupo originó dentro de la dirigencia católica fueron notables y promovió el alejamiento de esas instituciones de varios socios eminentes. ${ }^{57}$

Siempre estuvo presente en las primeras décadas del siglo XX en Córdoba una dirigencia católicoconservadora muy influyente. De todos modos, la mayoría se fue adecuando paulatinamente a los nuevos tiempos y lo hizo, ocupando lugares destacados en las instituciones partidarias, en vez de forjar una agrupación compacta de católicos sociales, pero sin perder su característica de cacicazgo que traía desde antes de 1912. Pese a que la Doctrina Social de la Iglesia era ampliamente conocida como queda en evidencia en las discusiones llevadas a cabo en el Primer Congreso Diocesano de 1918, fue muy difícil para las élites tradicionales reunirse con el fin de llevar a la práctica las propuestas de la Encíclica Rerum Novarum. Empero, algunos integrantes, como lo demuestran las series ${ }^{58}$ realizadas al analizar las comisiones directivas del Círculo de Obreros, de la Sociedad Católica Popular Italiana, de los Josefinos y de la Asociación de Obreros de la Sagrada Familia, decidieron formar parte de las comisiones directivas de esas organizaciones para trabajadores. El catolicismo social puesto de manifiesto por este tipo de asociaciones fue particularmente impulsado por sacerdotes regulares (un jesuita respecto de los Josefinos), seculares (es el caso de la AOSF) o laicos de diversas clases sociales como sucedió con la creación y permanencia del Círculo y de la SCPI. A su vez es interesante remarcar que los consejos directivos y los socios de cada una de ellas, en términos generales no se superponían, sino que se trataba de grupos diferentes. Así, la SCPI como su nombre lo indica estaba constituida por italianos (trabajadores, pequeños comerciantes, jornaleros, entre otros) y sus descendientes, la AASJ mayoritariamente por trabajadores -la élite católica se agrupó en la Comisión Protectora-, el Círculo fue sumamente heterogéneo y salvo los presidentes, el resto de los miembros, en gran parte, provenía de sectores medios y trabajadores, por último la Asociación Obrera de la Sagrada Familia fue constituida en Bo. Inglés (un barrio marginal para la época) por el cura Sebastián Raggi,

\footnotetext{
57 El nombre más notable es el de Emilio Sánchez, presidente del Círculo desde 1926 a 1932. Sobre estos conflictos ver: Burgos, Ma. Beatriz; "Asociaciones católicas para obreros: Córdoba 1930-1943. Iglesia católica y cuestión social”; Tesis de Licenciatura en Historia; FFyH-UNC; 2013.

58 Categoría extraída de Ginsburg et al, 1991 [1989]. Ginzburg; Carlo, Castelnuovo; Enrico, Poni; Carlo; A Micro-História e outros ensaios; Difel; Lisboa; 1991 [1989]. Ver cap. V “O Nome e O Como. Troca Desigual e Mercado Historiografico".
}

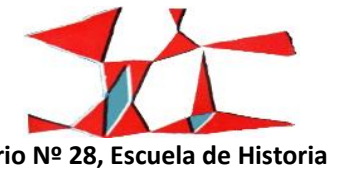

Facultad de Humanidades y Artes (Universidad Nacional de Rosario), 2016 
y la gente que lo acompañó provenía de comerciantes y trabajadores que no se superponía con las direcciones de las otras sociedades.

Estas instituciones católicas para trabajadores en el siglo XX estaban constituidas respetando un pattern absolutamente moderno sea por su funcionamiento, sus objetivos, su estructura organizacional. En ese sentido y a diferencia de los dirigentes más conservadores, en ellas los socios no solo podían obtener asistencia material -además de la espiritual-, sino que estaban habilitados en grados diferentes para ejercitar una participación ciudadana -desde antes de 1912- al elegir a sus representantes y participar en las asambleas generales donde además de las elecciones se discutían otros asuntos de la institución. La democracia interna era permitida entre los socios varones, incluso en algunos casos las mujeres también tuvieron algún grado de intervención como argumento en otros trabajos. ${ }^{59}$

Sin embargo, en Córdoba a diferencia de otras ciudades, el proceso de sindicación católica de los trabajadores no se produjo, a lo sumo -como sostiene Blanco- hacia fines de la década del treinta, comienzos de los cuarenta cuando grupos de trabajadores como los de Luz y Fuerza, acudían a sacerdotes para pedirle sugerencias sobre cómo iniciar la organización de un gremio. ${ }^{60}$ Es probable, que el asociacionismo católico se convirtiera en un instrumento suficiente para los trabajadores católicos y, sobre todo, para sus dirigentes a fin de satisfacer las necesidades indispensables. Respecto de los Josefinos es interesante subrayar la expansión que tuvieron en diferentes barrios de la ciudad a medida que esta se ampliaba demográfica y geográficamente.

En síntesis, el "nuevo catolicismo" que va surgiendo en Córdoba en las primeras décadas del s. XX es el resultado de una tensión no solo entre diferentes ideas de los miembros de la iglesia y los laicos, sino que esa diferenciación se manifiesta de múltiples formas, como si fuera una paleta de colores, que refleja desde los notables que se adhieren a uno u otro partido político, a intelectuales que defienden teorías claramente medievales para la época, organizaciones para trabajadores que pretenden poner en práctica las líneas provenientes de la Rerum Novarum para desafiar a la izquierda, una avanzada notable de la participación

59 Vidal, Gardenia; “Asociacionismo, catolicismo y género. Córdoba de entresiglos (XIX-XX)" en PROHISTORIA versión On-line, Rosario; núm. 20; ISSN 1851-9504; Portal Scielo; 2014 http://www.scielo.org.ar/scielo.php?script=sci issuetoc\&pid=1851$950420130002 \& \operatorname{lng}=\mathrm{es} \& \mathrm{nrm}=\mathrm{iso}$

60 Blanco, Jessica; "Religión, sindicalismo y política en los años '40: una revisión sobre la participación católica en los sindicatos durante los años formativos del peronismo" en Gardenia Vidal y Jessica Blanco (comps); Catolicismo y política en Córdoba, siglos XIX y XX; Ferreyra Ed.; Córdoba, 2010.

65

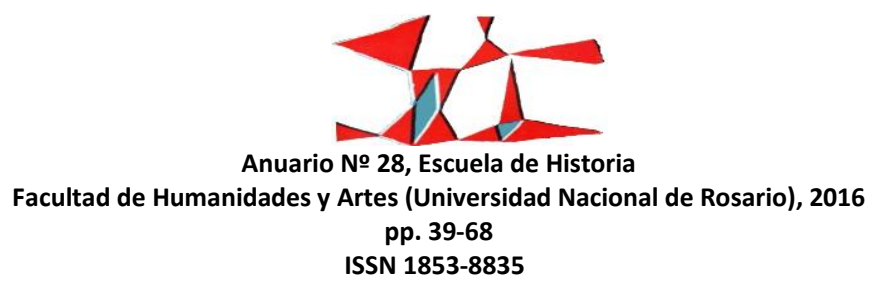


activa de las "masas" en defensa del catolicismo. ¿Qué catolicismo? Uno que invocaba a veces la Doctrina Social de la Iglesia, otras, la defensa de la Nación y la Patria, o la de la Virgen María y su desprendimiento, o San José y su dedicación al trabajo.

Los notables no desaparecieron ni siquiera de los partidos políticos, el caso de los Bas (Arturo y José Ignacio) es un ejemplo destacado de los incorporados a la UCR, pero ya no podían ellos solos decidir los lineamientos católicos, no me refiero a la doctrina, sino a la política que la iglesia llevaba adelante. La tensión interna fue la regla del "nuevo catolicismo", no obstante las "masas" católicas comenzaron a ganar las calles.

Por fin la Reforma Universitaria y el desafío que significó para los católicos fue contestado y los jóvenes estuvieron al frente de esas organizaciones antireformistas. En este sentido, la Reforma -que no se circunscribió a 1918, sino que continuó sus reclamos durante toda la década del '20 y más allá- sirvió de unión del catolicismo de Córdoba. El enemigo ya no se trataba de pequeños grupos de socialista o anarquistas, sino que había crecido palmariamente y seguía haciéndolo. La hegemonía conservadora del "público" cordobés en la que se insertaban los católicos, corría riesgos por la formación de "contra públicos subalternos", en palabras de Nancy Fraser. ${ }^{61}$

\section{Bibliografía}

Blanco, Jessica; “Religión, sindicalismo y política en los años '40: una revisión sobre la participación católica en los sindicatos durante los años formativos del peronismo" en Gardenia Vidal y Jessica Blanco (comps), Catolicismo y política en Córdoba, siglos XIX y XX, Ferreyra Ed., Córdoba, 2010.

Boixados, Cristina; "Vivienda y moral. La acción de la Comisión Protectora de los Artesanos de San José, 1900-1930" en G. Vidal y P. Vagliente (comps.) Por la Señal de la Cruz. Estudios sobre la Iglesia Católica y sociedad en Córdoba, S. XVII-XX; Ferreyra Ed.; Córdoba, 2002.

Burgos, Ma. Beatriz, “Asociaciones católicas para obreros: Córdoba 1930-1943. Iglesia católica y cuestión social", Tesis de Licenciatura en Historia, FFyH-UNC, 2013.

${ }^{61}$ Fraser, Nancy; lustitia Interrupta, Reflexiones críticas desde la posición "postsocialista"; Ed. Siglo del Hombre, Bogotá; 1997.

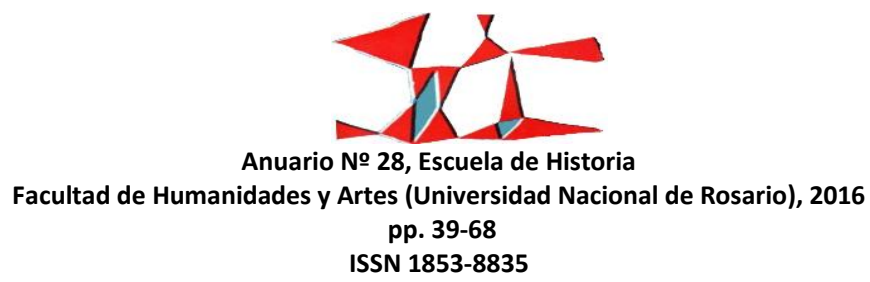


Clark, Christopher; "The New Catholicism and the European Culture Wars", en Clark Christopher and Kaiser Wolfram, Culture Wars: Secular-Catholic Conflict in Nineteenth Century Europe; Cambridge University Press; New York; 2003.

Chaves, Liliana; Tradiciones y Rupturas de la Élite Política Cordobesa (1870-1880). La clave conservadora de la modernización política; Ferreyra Ed.; Córdoba; 1997.

Di Stefano, Roberto; Sábato, Hilda; Romero, Luis A. y Moreno, José Luis; De las cofradías a las organizaciones de la sociedad civil. Historia de la iniciativa asociativa en Argentina; Edilab; Buenos Aires; 2002; pp. 33-41.

Fraser, Nancy; lustitia Interrupta, Reflexiones críticas desde la posición "postsocialista"; Ed. Siglo del Hombre; Bogotá; 1997.

Ginzburg, Carlo, Castelnuovo, Enrico, Poni, Carlo; A Micro-História e outros ensaios; Difel; Lisboa; 1991 [1989].

Moretti, Nicolás D.; Buenos cristianos y honrados ciudadanos. La obra salesiana y la cuestión social. Córdoba, 1905-1930; Centro de estudios Históricos; Córdoba; 2014.

Roitenburd, Silvia; "El papel de las mayorías en el proyecto global del nacionalismo católico (1910-1919)" en El Reformismo en Contrapunto. Los procesos de modernización en el Río de la Plata (1890-1930); CLAEH: argumentos; Montevideo; 1989; p.31.

Rock, David; La Argentina autoritaria. Los nacionalistas, su historia y su influencia en la vida pública; Ed. Ariel; Buenos Aires; 1993; p.88

Scott, Joan Wallach; La mujeres y los derechos del hombre. Feminismo y sufragio en Francia, 1789-1944; Siglo XXI; Buenos Aires; 2012 [1996]; ]; pp. 15-24.

Vagliente, Pablo; "Sociedad civil. Cultura política y debilidad democrática en Argentina: explicando el colapso constitucional desde el caso Córdoba, 1850-1930"; Tesis de Doctorado, Facultad de filosofía y Humanidades; Universidad Nacional de Córdoba; 2010; pp.250-252

Vidal, Gardenia; Radicalismo de Córdoba 1912-1930. Los grupos internos: alianzas, conflictos, ideas, actores, Dirección General de Publicaciones Universidad Nacional de Córdoba; Córdoba; 1995.

Vidal, Gardenia; "Intentos de centralización desde el Papado: La Unión Popular Católica Argentina en Córdoba", en Gardenia Vidal y Jessica Blanco (comps.); Ferreyra Ed; Córdoba; 2010.

67

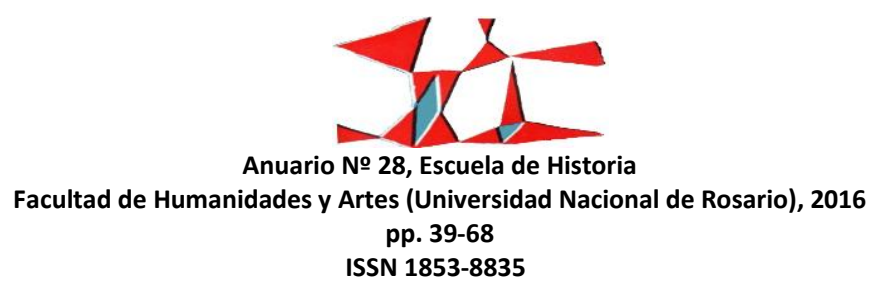


Vidal Gardenia (directora), Reseña biográfica de dirigentes que interpelaron el mundo del trabajo en Córdoba 1900-1950, 2014, http://www.ffyh.unc.edu.ar/sites/default/files/ebooks/

EBOOK_RESENABIOGRAFICA.pdf

Vidal, Gardenia, "Asociacionismo, catolicismo y género. Córdoba de entresiglos (XIX-XX)" en PROHISTORIA versión On-line, Rosario, núm. 20, ISSN 1851-9504, Portal Scielo, 2014 http://www.scielo.org.ar/scielo.php?script=sci issuetoc\&pid=1851-950420130002\&lng=es\&nrm=iso

Zandrino, Estefanía; Tesis de Grado "El Partido Comunista de Córdoba (1918-1927): origen, organización, dirigencia, relación con el mundo del trabajo y estilos de sociabilidad"; Escuela de Historia; FFyH-UNC; 2013.

Zandrino, Estefanía, y Vidal, Gardenia; "Una aproximación al Partido Comunista de Córdoba desde su fundación hasta fines de la década del veinte", en Gardenia Vidal y Jessica Blanco (eds.); Espacio público en Argentina, fines s. XIX-primera mitad s. XX. Partidos, catolicismo, sociabilidad...; Ed. Brujas; Córdoba; 2016.

Recibido: 9 de Agosto de 2016 Aceptado: 23 de septiembre de 2016 Versión Final: 2 de diciembre de 2016 